\title{
TROPOFIGURES AS NEW REALITIES OF TEXTS IN MODERN POLITICAL COMMUNICATION ${ }^{1}$
}

\author{
Natalya A. Bozhenkova \\ Pushkin State Russian Language Institute, Moscow, Russia \\ Tamara I. Kalichkina \\ Pushkin State Russian Language Institute, Moscow, Russia \\ Aleksandra P. Panteleeva \\ Pushkin State Russian Language Institute, Moscow, Russia
}

\begin{abstract}
The article examines the mechanisms of organizing verbal constructs that manifest the linguopragmatic structure of texts in modern Russian political communication. A special class of figurative means of political language stands out - tropofigures. Tropofigures include irony and parcelling, which are characterized, on the one hand, by formal-semantic ambivalence and, on the other hand, by an apparent idiostylistic touch. The proposed methodological framework of the study aimed at the identification and systematic characterization of the categorical features of these synergetic linguistic signs, facilitated the description of the ways of their exemplification in political interactions. The authors established that the tropofigures of irony and parcelling ornamentally form the antinomy of the identity / non-identity of the sign and the object (semasiological discrepancy between the logical and grammatical organization of the syntagma). The tropofigures not only organize the expressive-pragmatic center of political discursive practice but also fulfill the function of a verbal marker of the cognitive mechanisms of text formation, which allow the participant to present their communicative goal setting in a certain way. The authors emphasized that the tropofigures of irony and parcelling are transformed from means of enhancing expressiveness into markers of the idiomental process and set a different social perception. The results of the linguistic rhetorical research indicate new mechanisms of convergence / divergence of semantic constructs in various political interactions and, as a result, linguocultural "reaccentuation" of sign-symbolic and axiological constituents of the political institution in the modern Russian-speaking space.

$\vec{\widetilde{ }} \quad$ Key words: political discourse, tropofigure, irony, parcellation, cognitive mechanisms, emotive-expressive means, linguocultural markers.

Citation. Bozhenkova N.A., Kalichkina T.I., Panteleeva A.P. Tropofigures as New Realities of Texts in Modern Political Communication. Vestnik Volgogradskogo gosudarstvennogo universiteta. Seriya 2. Yazykoznanie [Science Journal of Volgograd State University. Linguistics], 2021, vol. 20, no. 2, pp. 57-73. (in Russian). DOI: https:// doi.org/10.15688/jvolsu2.2021.2.6

\section{ТРОПОФИГУРЫ КАК НОВЫЕ РЕАЛИИ ТЕКСТОВ СОВРЕМЕННОЙ ПОЛИТИЧЕСКОЙ КОММУНИКАЦИИ ${ }^{1}$}

\author{
Наталья Александровна Боженкова \\ Государственный институт русского языка им. А.С. Пушкина, г. Москва, Россия \\ Тамара Игоревна Каличкина \\ Государственный институт русского языка им. А.С. Пушкина, г. Москва, Россия
}




\title{
РЕЧЕВЫЕ МЕХАНИЗМЫ И ЕДИНИЦЫ ТЕКСТОВОЙ КОММУНИКАЦИИ
}

\author{
Александра Павловна Пантелеева
}

Государственный институт русского языка им. А.С. Пушкина, г. Москва, Россия

\begin{abstract}
Аннотация. В статье рассматриваются механизмы организации вербальных конструктов, манифестирующих лингвопрагматическую устроенность текстов современной российской политической коммуникации. В этой связи выделяется особый класс изобразительных средств политического языка - тропофигуры, к числу которых отнесены ирония и парцелляция, характеризующиеся, с одной стороны, формально-семантической амбивалентностью, с другой - явной идиостилистической окрашенностью. Представленная статья является результатом совместной работы авторов под руководством Н.А. Боженковой, предложившей методологическую концепцию исследования, направленную на вычленение и системную характеризацию категориальных признаков данных синергетических языковых знаков, что позволило описать способы их экземплификации в политических интеракциях. В процессе исследования установлено, что тропофигура иронии (Т.И. Каличкина) и тропофигура париелляции (А.П. Пантелеева), орнаментально оформляющие антиномию тождественности / нетождественности знака и объекта (семасиологическое несоответствие логико-грамматической организации синтагмы), не только организуют экспрессивно-прагматический центр политической дискурсивной практики, но и являются вербальным маркером когнитивных механизмов текстообразования, которые позволяют партиципанту определенным образом презентовать собственную коммуникативную целеустановку. Показано, что из приемов и средств усиления выразительности тропофигуры иронии и парцелляции преобразуются в маркеры идиоментального процесса и задают иной способ мировосприятия членов социума. Результаты проведенного лингвориторического исследования свидетельствуют о новых механизмах конвергенции / дивергенции смысловых конструктов в различных политических интеракциях и, как следствие, лингвокультурной «переакцентуации» знаково-символических и аксиологических конституентов политического института современного русскоязычного пространства.

Ключевые слова: политический дискурс, тропофигура, ирония, парцелляция, когнитивные механизмы, эмотивно-экспрессивные средства, лингвокультурные маркеры.

Цитирование. Боженкова Н. А., Каличкина Т. И., Пантелеева А. П. Тропофигуры как новые реалии текстов современной политической коммуникации // Вестник Волгоградского государственного университета. Серия 2, Языкознание. -2021. - Т. 20, № 2. - C. 57-73. - DOI: https://doi.org/10.15688/jvolsu2.2021.2.6
\end{abstract}

\section{Введение}

Латинский по происхождению термин фигура речи (лат. figura - «очертание, образ, вид»), обозначающий «стилистический прием, словесный оборот, используемый для усиления выразительности речи» (БАС, стб. 1344), с завидным постоянством оказывается в поле зрения исследователей, интересующихся проблемами риторической функции языка и массовой коммуникации. Более того, далеко не во всех областях знания можно обнаружить такую приверженность традиции, как в риторической теории. Несмотря на то что на протяжении 26 веков существования риторической мысли сформировалось большое количество различных школ и научных течений, к концу ХХ в. термин фигура речи стал интерпретироваться как совокупность исторически сложившихся и усовершенствованных в процессе общения «особых» приемов в построении фразы, сущностно являющихся средством усиления высказывания и направленных на повышение эффективности коммуникативного акта, причем «одновременно и внесловесной (содержательной), и словесной (формальной) его сторон» [Корольков, 1974, с. 64-65].

При всей внешней убедительности такое понимание фигуры речи скрывало внутри себя один малозаметный, но весьма существенный изъян: концепция истолкования фигуры как некоего противоречащего «обычному» способу языкового общения преобразования речи распространялась не только на филогенетический, но и на онтогенетический аспект проблемы. Соответственно, принято было считать, что говорящий (пишущий) сначала непременно использует в качестве исходного «сырого материала» некое «нефигуральное» выражение, в дальнейшем подвергающееся авторскому же видоизменению путем включения искусственных приемов, которые «якобы можно беспрепятственно вводить в речь и также свободно устранять из нее» [Корольков, 1974, с. 65]. Лишь постепен- 
но учеными стало осознаваться, что фигурация речи, выступающая результатом определенных усиливающих преобразований мыслительно-словесного «материала», возможна, но этот случай отнюдь не является правилом ${ }^{2}$. «...Пишущие (говорящие) не украшают с помощью фигур то, что пишут, они создают язык... Таким образом, “дополнительные структуры" не являются простыми ограничителями, пусть “чудесными", но “тисками”: они представляют собой то единственное средство, которое может увести язык от его утилитарной роли..» [Дюбуа и др., 1986, с. 60].

Наибольшую сложность при описании категориальной сущности фигур речи вызывал вопрос о соотношении тропа и стилистической фигуры, помещаемых в общем разделе орнаментальной части любой риторики. Отметим, что в филологической традиции существуют различные интерпретации природы и границ рассматриваемых явлений: в широком (как правило, логико-семиотическом) понимании фигуры включают в себя тропы ${ }^{3}$, в семантико-прагматическом же они обычно разграничиваются ${ }^{4}$. Так, касаясь дифференциации тропов и фигур, А.Г. Горнфельд писал: «Троп есть форма поэтического мышления; фигура есть форма речи. Тропы имеют результатом обогащение мысли известным новым содержанием; фигуры - определенные обороты речи, рассчитанные на известное действие, но не вносящие в содержание ничего нового, расширяющего познание. Они служат выражением эмоционального движения в говорящем и средством передачи тона и степени его настроения слушателю» [Горнфельд, 1911, с. 335].

Неоднозначность исследовательских подходов объясняется многими факторами - от экзистенциональности взглядов мыслителей и ученых, специфики научных / практических задач сочинения до принципов описания собственного языкового материала. Бесспорно, в качестве доминант экспрессивно маркированной речи выступают как тропы, так и стилистические фигуры, однако в категориальном плане они имеют существенные отличия: первые строятся по принципу референтного смещения, образной иносказательности, на основе ассоциаций по сходству / смежности / противоположности, вторые же детерминированы орнамен- тальным, явно отступающим от нейтрального речевым ходом, суммирующим прямые (непереносные) значения компонентов высказывания, что предполагает особые способы соединения слов, словосочетаний, предложений или более крупных фрагментов текста.

Вместе с тем ряд изобразительных средств и приемов (например, сравнение, оксюморон, хиазм и др.) с точки зрения выдвигаемых критериев оказываются в силу своей природы переходными и таксономически не вполне мотивированными. В этой связи представляется интересной идея Л.А. Новикова, предлагавшего выделить особый класс экспрессивных средств - тропофигу$p b l$, включающий те орнаментальные конструкции, разграничение которых возможно только до известной степени: «Если взять, скажем, сравнение, то оно обнаруживает свойства как тропа (“несвернутая” метафора), так и фигуры (конструкции с союзами

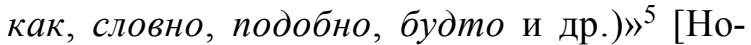
виков, 2002, с. 122].

Аналогичные признаки (совмещения характерологических черт как тропеических единиц, так и собственно фигурных построений), с нашей точки зрения, обнаруживают также ирония и париелляция: именно синергия их структурно-семантической организации определяет возможность перехода «от индивидуального ко всеобщему». Более того, каждая актуализация парцеллированной конструкции или синтагмы с ироническим кодом в силу внутренней тропеической активности и неограниченности фигурной модели реализует какиелибо лингвокультурные смыслы (не всегда вербализованные, но обязательно существующие латентно) и одновременно обусловливает их «жизнеспособность» в современной логосфере, важнейшей частью которой, бесспорно, является политическая коммуникация.

Несмотря на внушительный ряд исследований, посвященных специфике речевого взаимодействия в политической сфере, в изучении политического дискурса прослеживается ряд нерешенных проблем. К их числу следует отнести поиск метаязыкового описания и, как следствие, характеризацию коммуникативного поведения политиков в терминах речевого воздействия. Отметим, что необходимость исследования языка политических 


\section{РЕЧЕВЫЕ МЕХАНИЗМЫ И ЕДИНИЦЫ ТЕКСТОВОЙ КОММУНИКАЦИИ}

субъектов обусловлена как тенденцией «орализации» [Стернин, 2003, с. 105] политического дискурса ${ }^{6}$, так и научной значимостью моделирования ментальных структур участников политической коммуникации.

Политический дискурс, представляющий собой речевую деятельность субъектов в сферах политического институционального общения, детерминированную определенной социально-ролевой иерархией и объективированную в виде совокупности текстовых единиц политической направленности во всем их жанровом и функциональном многообразии [Боженкова Н.А., Боженкова Р.К., Боженкова А.М., 2017, с. 258], оказывается наиболее «чувствительным» к различного рода трансформациям. Базисный признак политического дискурса - его использование в качестве инструмента овладения властью, ее сохранения и перераспределения - детерминирует организацию и реализацию в политических интеракциях текстовых единиц различной формы (от описания до выводов), разнообразных жанров (от официального заявления до интервью), которые, наряду с эксплицитной информацией, непременно содержат имплицитноконнотативные элементы - в первую очередь эмотивно окрашенные языковые конструкты. Неслучайно В.И. Шаховский утверждает, что «народу важен не столько смысл сказанного, сколько эмоции, рожденные сказанным, манипулирование общественным сознанием власть осуществляет при помощи языка» [Шаховский, 2008, с. 37]. Именно такие вербальные знаки в наибольшей степени определяют особую языковую картину политического дискурса и его дифференциальные характеристики - специфическую институциональность, ритуальность и смысловую неопределенность, восстановление которой возможно благодаря неразрывной связи политических текстов с социокультурными, аксиологическими, идеологическими, историческими, психологическими компонентами коммуникативной ситуации, в которой они были созданы, и одновременно с системой когнитивных и прагматических установок адресанта, взаимодействующего с адресатом.

Соответственно, эффективность политического дискурса определяется адекватным планированием коммуникативного поведения автора и умелым воплощением этого плана путем использования различных, реализующих воздействующий потенциал естественного языка на эмоционально-волевую и интеллектуальную сферу адресата вербальных средств, в кластере которых тропофигуры занимают особое место.

\section{Материал и методы}

Методологическая концепция исследования, направленная на системную характеризацию лингвориторических маркеров политических интеракций, позволила обнаружить новые способы языковой экспликации аксиологических и символических конституентов поля политики. Когнитивно-дискурсивный фокус исследовательских взглядов авторов определил основные методы исследования - от функционально-прагматического рассмотрения текстовых единиц, описательно-логических приемов сопоставления его категориальных составляющих до контекстуального анализа и метода лингвокультурологических истолкований речевых актов, что дало возможность выявить в лингвистическом объекте новые свойства и на этом основании систематизировать лингвокультурные закономерности организации политических дискурсивных практик.

Материалом исследования послужили скрипты публичных выступлений (имеющих тематическую и жанровую общность) представителей российской политической элиты, особое внимание отводилось опубликованным в официальных источниках пресс-релизам, текстам брифингов, комментариев в социальных сетях, эксплицирующих сущностное единство (при неоднозначности идеологических позиций и специфичности идиорепрезентации) лингвориторических конституентов политического пространства (более 500 текстовых единиц).

\section{Результаты и обсуждение}

Политический дискурс как публичная коммуникативная сфера обладает рядом отличительных особенностей, наиболее точно охарактеризованных Р. Водак: «Он находится как бы между двумя полюсами - функцио- 
нально-обусловленным специальным языком и жаргоном определенной группы со свойственной ей идеологией. И должен выполнять противоречивые функции, в частности должен быть доступен для понимания (в соответствии с задачами пропаганды) и ориентированным на определенную группу (по историческим и социально-психологическим причинам)» [Водак, 2011, с. 24]. В этой связи вербальные знаки политического дискурса имеют ряд отличий от повседневной речи: языковые единицы «приобретают» нетипичную для них интерпретацию, «наполняются» противоположным смыслом, тем самым констатируется коннотативная амбивалентность трансляции идеологически маркированных единиц, определяемая «не столько принципиальными политическими установками коммуникантов, сколько латентными целями управления аудиторией» [Боженкова и др., 2019, c. 78]. Важным является и тот факт, что особая институциональность политического дискурса, обусловленная личностными характеристиками агента дискурсивной практики (градуальность интеракции коррелирует с видом коммуникативного события и варьируется в зависимости от степени включенности персонального компонента), нередко детерминирует невозможность эксплицитного маркирования идеологем, в результате расширяется тезаурус прецедентных текстов и высказываний, сопровождаемых своеобразными речевыми приемами и определенным звуковым оформлением, что в риторической традиции называется иронией и паризелляиией. В результате политический текст, актуализируя обыденно незамечаемые семиотико-семасиологические компоненты, порождает новый, единственно истинный смысл высказывания.

Несомненно, что вербальные средства передачи информации специфичны для каждого политика: они зависят от культурноисторического контекста, политической ситуации, цели и методов ее достижения, однако сегодня с уверенностью можно говорить о некоем «ироническом отношении» к реальности, которое приобретает всеобъемлющий характер, при этом структурно-композиционным оформлением передачи иронического кода нередко выступает парцеллированная конст- рукция. Актуализация данных тропофигур в политических интеракциях и расширение сферы коммуникативных рисков, обусловленное их частотным включением в политические дискурсивные практики, становятся стимулом как для характеризации их лексическоморфологических, логико-синтаксических, семантических компонентов, так и для описания тенденций развития этих феноменов.

\section{Tропофигура иронии в контексте} современной политической коммуникации ${ }^{7}$

Явление иронии, отражающее одну из сущностных категорий человеческого бытия, с древнейших времен изучается с разных позиций - эстетической, риторической, литературоведческой, лингвистической, искусствоведческой. Античная трактовка иронии соединяла в себе философское и эстетическое начало, ставшее основой для дальнейшего разделения терминологического описания риторической и логической иронии, а также иронии как способа человеческого бытия. Ирония в таком осмыслении (актуальном до $\mathrm{XX}$ в.) - это восприятие ситуации с положительной стороны, оно перекликается со «спасительным смехом», помогающим «не впадать в депрессию». В XX в. ключом к понимаю иронии становится теория К.В.Ф. Зольгера, определявшего иронию как «средоточие искусства, где достигается совершенное единство созерцания и остроумия и которое состоит в снятии идеи самой же идеей» [Зольгер, 1978 , c. 421].

В отечественной лингвистике базовое определение иронии принадлежит В.И. Далю: «Речь, которой смысл или значение противоположно буквальному смыслу слов; насмешливая похвала, одобрение, выражающая порицание» (Даль, т. 2, с. 273) ${ }^{8}$. Первым отечественным исследователем, отказавшимся от одностороннего понимания иронии, стал А.А. Потебня. Согласно его концепции, ирония как явление разделяется на иронию-троп и иронию-смысл [Потебня, 1990]. Различие состоит в сопровождении иронии-смысла экстралингвистическими факторами и, как результат, в возникновении у адресата определенного чувства на основании рецепции полиформного иронического 


\section{РЕЧЕВЫЕ МЕХАНИЗМЫ И ЕДИНИЦЫ ТЕКСТОВОЙ КОММУНИКАЦИИ}

кода. Соответственно, ирония связана не только с вербальным ее выражением, но и с невербальными средствами коммуникации, лингвокультурными компонентами и интертекстуальными явлениями.

В настоящее время трактовка феномена иронии опирается на синергию философского и лингвистического подходов. Философское понимание иронии актуализирует рефлексию автора, которая в свою очередь становится средством отражения действительности, непосредственно его окружающей. Различаются и способы этого восприятия: критический, эмоционально-оценочный, эстетический, интерпретирующий (как средство истолкования событий) и др. С лингвистической точки зрения ирония направлена на собеседника и представляет собой способ «донесения» до адресата отношения адресанта к чему-либо с помощью знаковых (в широком значении) конституентов [Каличкина, 2017]. Суммирование подходов дает возможность определить иронию как тропофигуру, сущностно являющуюся мультисмысловой системой вербальных единиц, «спаянных» интер- и контекстуальностью, формально представленную синтагматическими отрезками любого размера и позволяющую эксплицировать разнообразное эстетическое, этическое или аксиологическое содержание.

В контексте политического дискурса тропофигура иронии демонстрирует персонифицированное восприятие организации универсума, находящее свое отражение в языке, и используется субъектами политического пространства для диффамации оппонента. Тем самым в политических интеракциях актуализируется авторизация, усиливается модус художественности, наблюдается снижение клишированности: политический дискурс приобретает черты бытийного, а тропофигура иронии оказывается моделью мировосприятия культурно обусловленных реалий, возникающих в результате семантико-стилистического взаимодействия «своей» и «чужой» речи, что порождает смысловую неоднозначность и многослойность высказывания.

Функции иронии в рамках политического взаимодействия могут варьироваться в зависимости от ситуации, однако явно выделяются две из них. Первая (о чем уже было сказано) - это языковое самовыражение политика, передача личностного отношения к ситуации, результативность которой сложно переоценить в условиях видоизменения прагматической нагрузки политической дискурсивной практики, когда к трем основным параметрам (информирование, манипуляция и контроль) добавился четвертый, свойственный ранее лишь СМИ, - развлечение аудитории. Второй важной функцией иронии следует считать вуалирование нападения на оппонента, сокрытие инвективных стратегий, поскольку при построении диалогического взаимодействия в политической среде значимость вербальных и невербальных средств, снимающих «напряженность контекста», многократно увеличивается. Выстраивая коммуникативную практику в ироническом ключе, партиципанты, нагружая дискурсивные компоненты имплицитными мелиоративными коннотациями, вместе с тем не унижают собеседника, а формируют оптимистический фон интеракции.

Отметим, что тропофигура иронии придает политическому тексту дополнительную образность, яркость, он становится более запоминаемым и эффективнее воздействует на аудиторию. Таким образом, можно сделать вывод, что политический дискурс с ироническим кодом предполагает с позиции автора наличие скрытых сюжетных схем, цель которых - убедить аудиторию в истинности своей речи; с позиции же адресата - знание этнокультурных и исторических особенностей, этических и аксиологических законов той страны, гражданином которой является политик.

В качестве доказательства нашего тезиса проанализируем выступления директора Департамента информации и печати МИД РФ М.В. Захаровой:

(1) Ммммм... История с закрытием счетов RT в Великобритании перестает быть томной. Она начинает попахивать, и не чем-нибудь, а Би-Би-Си. А это, как в детской песенке про Братца Кролика: «Если близко лисий хвост, значит близко лиска». За дело взялась русскоязычная дочка рупора Ее Величества, буквально за сутки «накопав» на российский телеканал ... а ничего не накопав. Так бывает: копали, копали и не накопали. Большой материал и ни о чем. Зачем? А чтобы осадочек остался. Немного напоминает историю Леонида Свиридова 
(https://www.facebook.com/leonid.sviridov.3). Чтобы придумать предлог для выдворения корреспондента РИА Новости из Польши за проведенную выставку памяти Стенина, польские власти запустили слух о том, что он «не совсем журналист». И тут же, как по команде, тему подхватили все кому не лень. Больше всех старались отдельные личности на «Эхе». Эфир за эфиром. Смешно получилось. Потому что в результате копаний выяснилось, что все эти годы Леонид Свиридов был внештатным сотрудником организации из трех букв, но не той, на которую так намекали и там, и тут, а другой Эха. Да-да, именно эта запись в трудовой книжке была найдена по итогам «журналистского расследования». Чувствую, как-то так будет и в этот раз. Но в любом случае, русскоязычной службе Би-БиСи желаю удачи. Она ей сейчас понадобится, потому что раскопки - вещь такая, увлекательная и непредсказуемая (Facebook. M. Захарова. URL: https:// www.facebook.com/maria.zakharova.167?epa= SEARCH BOX).

В публикации дается комментарий события без включения прямых цитат, используются риторические вопросы, разворачивается игра с читателем: употребляются фразеологизмы (все кому не лень), прецедентные высказывания (перестает быть томной; начинает попахивать; осадочек остался), аллюзии на сказочные литературные произведения (копали, копали и не накопали; если близко лисий хвост, значит близко лиска); нет разрыва между первой частью текста и второй; публикация не озаглавлена; через всю канву текста идет стержневая линия, близкая к детективным жанрам, содержащая интригу и неожиданное продолжение; явно вычленяется когнитивная метафора. Заканчивается публикация согласно детективным канонам - автор интригует, приоткрывает занавес, но не рассказывает, что произойдет дальше (раскопки - вещь такая, увлекательная и непредсказуемая). Текст насыщен размышлениями, обращениями к читателям, вводными конструкциями, намеками, что создает иронический код. В середине публикации текст захватывает читателя как текст художественного произведения, побуждая адресата ознакомиться со всей публикацией и узнать развязку. Читателю предлагаются неопровержимые факты, далее автор высказывает свои предположения о сложившейся ситуации, «сталкивает» ее с аналогичной и завершает мысль открытым финалом.

Ирония одновременно включена в сам текст и выходит за грани текста. Ироническая рефлексия появляется во фразе: $3 a$ дело взялась русскоязычная дочка рупора Ee Величества, буквально за сутки «накопав» на российский телеканал ... а ничего не накопав. После слов буквально за сутки «накопав» на российский телеканал читательское ожидание подсказывает, что далее будет следовать ссылка или цитата на текст o «раскопках», но автор прерывает ожидания категоричным отрицаем каких-либо фактов: обман читательского ожидания, антитеза, употребление разговорной лексики. Симбиоз этого приводит к комическому эффекту, в таком же стиле развивается повествование читатель на продолжение текста смотрит уже с иронической точки зрения, предполагая подвох, скрытый смысл. Далее в тексте появляется аналогичная конструкция: Леонид Свиридов был внештатным сотрудником организации из трех букв, но не той, на которую так намекали и там, и тут, а другой - Эха.

Логико-семантически иронический код в рассматриваемом тексте формируется посредством разнообразных приемов. Прежде всего актуализируется механизм пересечения и объединения, когда автор «присваивает объединению двух значений признак, присущий только их пересечению» [Дюбуа и др., 1986, с. 197]. М.В. Захарова объединяет две различные по смыслу ситуации, но схожесть фактов и аналогичность обстоятельств подталкивает читателей к определенным выводам. В данном примере реализуется следующая схема метафорического процесса: И - (П) - Р, где И - исходная ситуация (история с закрытием счетов $R T$ в Великобритании), $\mathrm{P}$ - результат, то есть достижение иронического эффекта, который формируется через промежуточный, объединяющий смысл - П (история с журналистом Леонидом Свиридовым).

Отметим, что при создании такой метафоры автор «автоматически» прибегает к синекдохе, так как сталкивает различные ситуации: здесь исходный прецедент является синекдохой для объединяющего смысла (несмотря 


\section{РЕЧЕВЫЕ МЕХАНИЗМЫ И ЕДИНИЦЫ ТЕКСТОВОЙ КОММУНИКАЦИИ}

на утверждение Р.О. Якобсона, что употребление в одном тексте синекдохи и метафоры невозможно). Соположение синекдохи и метафоры в анализируемом тексте обусловливается следующим: метафорический перенос строится на использовании двух конструкций, которые не столько контрастируют друг с другом, сколько определяют точку пересечения между исходной ситуацией и результатом. Такими конструкциями - синекдохами - служат ситуация с журналистом Леонидом Свиридовым, работающим на радио «Эхо», и закрытие счетов RT в Великобритании. В конечном счете они сводятся к единому результату, что создает метафоричность всего текста и вызывает иронический эффект.

В данном тексте вычленяется и референциальная метафора как семантическая структура, построенная на основе образов или мысленных представлений. Проанализируем логические связки. Начало текста «накопав» на российский телеканал ... а ничего не накопав включает метафору так, будто это синекдоха (через пересечения, опирающиеся на столкновение двух денотатов). Одновременно в высказывании смешивается истинное и ложное, что является отличительной чертой скорректированной метафоры. Помимо перечисленных риторических приемов, в тексте наличествует сравнение: Немного напоминает историю Леонида Свиридова. Создается некий треугольник, состоящий из синекдохи, сравнения и метафоры как логического завершения текста, который дополнительно приводит к ироническому осмыслению ситуации.

Прием сравнения использован и в высказывании $A$ это, как в детской песенке про Братиа Кролика: «Если близко лисий хвост, значит близко лиска». Кроме непосредственного сопоставления со сказкой Д. Харриса «Братец Лис и Братец Кролик», сопоставление обнаруживается и внутри приведенной цитаты из песни Братца Кролика. Прием грамматических связок, характерных для сравнения, можно увидеть и в конструкциях как-то так будет и в этот раз; попахивать и не чем-нибудь, а Би-Би-Си. Приведенные фрагменты устанавливают между сравниваемыми ситуациями отношения аналогии, то есть создается эквивалентность между события- ми, первоначально обладающими разной степенью сходства.

М.В. Захарова использует и еще один прием - грамматическое приложение: pacкопки - вещь такая, увлекательная и непредсказуемая, функция которого заключается в уравнивании двух частей с позиционной точки зрения и оформлении их, таким образом, в виде парадигмы.

Представляется, что мультисмысловая устроенность тропофигуры иронии, семасиологическими механизмами которой в данном случае являются как соединение нескольких типов риторических приемов, апеллирование к функциональной устроенности когнитивной метафоры, так и публицистически организованная структура текста (преамбула, основной тезис, антитезис, обоснования и вывод), чрезвычайно точно воздействует на референта сообщения, вызывая необходимую автору (иначе - единственно истинную) аксиологическую реакцию.

В качестве примеров реализации механизмов создания иронического кода в российском политическом дискурсе приведем также цитаты из выступлений президента РФ В.В. Путина.

(2) В отношении представителей прессы я могу сказать так, как в свое время мы шутили, когда я работал в совершенно другой организации: их прислали подглядывать, а они подслушивают... (Президент России. URL: http://kremlin.ru/events/ president/transcripts/23864).

В данном случае ирония строится на игре смыслов: переносное значение слова подглядывать, о котором первоначально подумали зрители, предполагает 'сбор информации любыми способами', однако происходит обман ожиданий реципиентов, поскольку лексема подглядывать используется в одном прямом значении.

(3) Должен сказать, что руки у России становятся все крепче и крепче. Выкругить их вряд ли представляется возможным, даже такому сильному партнеру, как Евросоюз (Президент России. URL: http:// kremlin.ru/events/president/transcripts/22150).

Контекст (3) - это демонстрация еще одного способа создания иронии - неожиданное завершение афоризма и изменение его 
смысла. В высказывании используются фразеологических единицы крепкая рука и выкручивать руки, имеющие два противоположных смысла, однако при включение их в одну синтагму они не противоречат, а дополняют друг друга и создают таким образом иронический эффект.

(4) «Кто управляет страной в то время, когда вы и президент России спите?» - «Мы спим по очереди. Все под контролем, не сомневайтесь» (Президент России. URL: https://www.vesti.ru/doc. html?id=414412).

Президент России «ушел» от прямого ответа, актуализируя лишь прямое значение глагола сnать (тогда как журналист понимал и его синонимический эквивалент 'бездействовать').

(5) Я не хочу сказать, что нам совершенно безразлично ваше мнение и что мы плевать на все хотели. Нет, мы будем прислушиваться к советам... доброжелательным (Президент России. URL: http:// kremlin.ru/events/president/transcripts/21775).

Здесь иронический код детерминируется антитезой, клишированной конструкцией с включением разговорных элементов, противопоставлением прямого значения переносному и (что особенно важно!) специальным паузированием и рематической акцентуацией последней языковой единицы.

Таким образом, тропофигура иронии, семасиологически организованная изменением смежности смыслов или форм (вплоть до их несовместимости) и имеющая многочисленные варианты репрезентации, оказывается не только языковой рамкой современного политического дискурса, но и неким культурным кодом взаимодействия властных структур и общества, при этом способ синтагматического оформления часто играет главенствующую роль, демонстрируя корреляцию тропофигуры иронии с тропофигурой парцелляции.

\section{Тропофигура парцелляции в контексте современной политической коммуникации}

В русской лингвистической традиции парцеллированные конструкции впервые были описаны Ю.В. Ванниковым, определившим их как «самостоятельные фразы, образующие вмес- те с полной структурой единое высказывание и единоепредложение» [Ванников, 1979, с. 102], им же был проведен теоретический анализ явления парцелляции и выделены основные функциональные типы. С конца 70-х гг. из-за смещения фокуса исследований в сторону прагматики парцелляция стала рассматриваться в аспекте ее коммуникативно-целевой нагруженности и разграничения собственно парцелляции и «смежных явлений»: «Парцелляция - явление динамического аспекта предложения. Это стилистический прием, состоящий в вычленении части высказывания, построенного по форме предложения, в самостоятельное высказывание, или, что то же самое, - представленность предложения в виде двух или нескольких фраз в экспрессивных целях» [Сковородников, 1981, с. 122] 9 .

В настоящее время большинство ученых отмечают, что парцелляция как способ организации текста связана с усложнением характера предикации, а значит, и с изменением схемы актуального членения предложения. В парцеллированных конструкциях, с одной стороны, продолжает действовать логическая предикативная связь, объединяющая основные компоненты актуального членения предложения - тему и рему - на уровне всего предложения, с другой стороны, «оживляются» синтаксические связи на уровне его частей. Парцеллированные конструкции обладают набором определенных признаков: 1) высказывание членится на две или более части, одна из которых представляет собой базовый компонент и содержит тему высказывания, а вторая - собственно парцеллят, всегда содержащий рему (нечто новое, нередко парадоксальное); 2) парцеллят - это не добавочная конструкция, а отчлененная часть уже существующей структуры, которая разграничивает высказываемые мысли и находится в постпозиции к базовой структуре; 3) на семантическом уровне парцеллят характеризуется идентичными с базовой частью временными семами; между частями расчлененной структуры сохраняются грамматические связи, которые при необходимости можно легко восстановить; предикативные признаки (модальность, синтаксическое время) заимствуются из базовой части; 4) модель предпарцел- 


\section{РЕЧЕВЫЕ МЕХАНИЗМЫ И ЕДИНИЦЫ ТЕКСТОВОЙ КОММУНИКАЦИИ}

лируемой структуры сохранена, даже если при парцеллировании был нарушен порядок слов; 5) парцеллированный компонент имеет самостоятельное интонационное оформление - предупредительная пауза перед парцеллятом, убыстренный темп, повышение тона в конце (что в письменной речи маркируется отделением от базовой части пунктуационным знаком точки, реже возможны тире, многоточие, вопросительный или восклицательный знаки); 6) благодаря сознательному интонационному отвлечению от синтаксически господствующей части, информация, содержащаяся в парцелляте, в соответствии с интенциями адресанта актуализируется, при этом высказывание приобретает особую (метафорическую) смысловую и эмоциональную выразительность.

Соответственно, парцеллированные конструкции не только акцентируют внимание на суперпозиции ремы высказывания, но и выполняют существенную роль в манифестировании смысла текста и авторской позиции, тем самым демонстрируют признаки тропофигуры. В свете сказанного можно утверждать, что, будучи синкретичным синтаксическим феноменом, в котором «соединяются черты двух позиций - присловной и неприсловной вне предложения с распространяемым компонентом» [Панков, 2019, с. 768], тропофигура парцелляции как лингвистический механизм текстообразования создает условия для преодоления языковых запретов на постановку в синтаксическую постпозицию различных словоформ и маркирует коммуникативно релевантный компонент высказывания, что детерминирует ее активное включение в те дискурсивные практики, где персуазивность, интерпретация и контроль выходят на первый план [Боженкова Н.А., Боженкова Р.К., 2019, с. 258].

Характеризуясь формально-семасиологической неоднозначностью, с одной стороны, и явной идиостилистической окрашенностью - с другой, парцеллированные конструкции, вероятно, «перешли» в политическую речь (впрочем, как и в речь публицистическую в целом) из речи разговорной, и собственно орнаментальной константе предшествовала речевая ошибка, детерминированная интонационным разрывом синтаксической связи между членами синтагмы и оформленная графически с грамматическим нарушением (в аспекте ортологии) границы предложения. Однако дальнейшее закрепление в речевой практике такой «диаграмматичности» (в терминологии Т.Г. Хазагерова), обусловленное рефлексией говорящего, что информация о количестве и порядке расположения, которую латентно «несет» эта тропофигура, вместе с соответствующей интонацией позволяет отображать не только семантически сопоставимые характеристики окружающей действительности (при разнородности дейксиса), но и внутренние ритмы психической деятельности, обеспечило им статус яркого стилистического феномена. Тропофигура парцелляции, эксплицируя целый спектр эмоциональных состояний и оценочно-модальных значений, предоставляет возможность партиципантам политического дискурса варьировать как аксиологическое наполнение высказывания, так и его прагматическую нагрузку. В этой связи тропофигуру парцелляции можно рассматривать не столько как одну из орнаментальных конструкций, сколько как способ реализации определенных лингвокультурных смыслов [Боженкова Н.А., Боженкова Р.К., 2020].

Анализ эмпирического материала и лингвистические наблюдения дают основания утверждать, что функциональная многоплановость парцелляции, незамкнутость ее лексического воплощения, достаточная свобода синтаксического представления (в пределах структуры простого / сложного предложения, однородных членов; вследствие эллипса глагола общего значения; контактность / дистантность расположения; степень распространенности и количественность парцеллята) приводят к тому, что парцеллированные конструкции в политическом дискурсе имеют разные модели.

Один из наиболее употребительных вариантов - парцелляция простого предложения с логическим выделением участников, обстоятельств или условий произошедшего, являющихся в употребляемом контексте значимой информацией. Имея вполне простую грамматическую структуру, подобная модель парцелляции оказывается уникальным когнитивным приемом в коммуникативном плане. Как правило, в самостоятельное высказывание выделяются конституенты, способность которых к отграничению определяется не столько структурой, сколько пропозиционными факторами и специфическими коммуни- 
кативными задачами: такие элементы разнообразны по морфологическому оформлению, что диктует и частотность их употребления в речи.

Наиболее типичны в роли парцеллятов (в силу их слабой связи с базовой частью и способности к детализации и актуализации) наречия и предложно-падежные сочетания наречного типа:

(6) Для людей важно, что реально сделано и как это улучшает их жизнь, жизнь их семей. И не когда-нибудь, а сейчас (Президент России. URL: http://kremlin.ru/events/president/news/59863);

(7) Националисты на Украине избили нашего стрингера Ruptly - после того как он взял интервью у прохожих об их отношении к Дню Победы. Работать на новостное агентство, имеющее отношение к России, на Украине сейчас смертельно опасно. Особенно в День Победы (М.С. Симоньян. URL: https://twitter.com/M_Simonyan/status/ 1391512535023636483).

Парцелляция дополнений, которые спаяны с глаголом, оказывается затрудненной, а чаще вовсе не возможной. Непрогнозируемые же дополнения, благодаря ослабленной семантической связи с доминирующим элементом, обладают большой способностью к парцеллированию:

(8) Забыли о главном - о людях. Об их интересах и потребностях (Президент России. URL: http:// kremlin.ru/events/president/news/56957);

(9) Но никогда, слышите, никогда и нигде никто не ставил мне условий нахождения в эфире. Кроме команды Навального (Facebook. M. Захарова. URL: https://www.facebook.com/ maria.zakharova.167?epa= SEARCH_BOX);

(10) Честно скажу, сегодня вечером час спала на диване в кабинете. Под пледом и пальто (Facebook. M. Захарова. URL: https://www.facebook. com/maria.zakharova.167?epa $=$ SEARCH_BOX);

(11) Я не знаю, проиграли мы эту первую битву или нет. И с кем мы вообе воюем: с вирусом? Или с самими собой? (Facebook. M. Захарова. URL: https://www.facebook.com/maria.zakharova. 167?epa=SEARCH_BOX);

(12) А почему у нас нельзя привиться иностранцам? Даже за деньги (М.С. Симоньян. URL: https://twitter.com/M_Simonyan/status/ $1384101857228845066 ? \mathrm{~s}=20$ ).

Продуктивной в системе простых предложений является модель с расчленением од- нородных членов, как правило одноформных сказуемых или определений:

(13) Наша страна всегда шла в авангарде освоения Вселенной. Будем делать все, чтобы уделять должное внимание и одному из важнейших направлений - пилотируемой космонавтике. Обязательно продолжим реализацию стратегических планов по освоению космоса. Будем развивать все наши программы» (Президент России. URL: http:// special.kremlin.ru/events/president/transcripts/ 63183);

(14) Его нет, отношения. Ни хорошего, ни плохого. Никакого(М.С. Симоньян. URL: https://twitter.com/ M_Simonyan/status/1386006946696794120?s=20).

Парцелляция разноформных членов встречается реже, однако, помимо экспрессивно-семантической, выполняет конструктивно-прагматическую функцию (в примерах ниже различение времени глаголов подчеркивает обещание продолжения действия):

(15) Факты о помощи. И она поступает. И будеm nостуnаmb (Facebook. M. Захарова. URL: https://www.facebook.com/maria.zakharova.167?epa= SEARCH BOX);

(16) А есть только витиеватые отношения с Турцией. Вот сейчас такие. Потом будут другие. Или не будут. Но армяне для США - просто ружьишко (М.С. Симоньян. URL: https://twitter.com/ M_Simonyan/status/1386006946696794120?s=20).

Отметим частотность использования в таких конструкциях союза $u$ в качестве вставки, который, восстанавливая плавность, ритмическое равновесие парцеллята и базовой части, способствует смягчению речевого разрыва.

Особое внимание обращают на себя парцеллированные конструкции, включающие (a) вводные / оценочные / модальные слова и (б) повторяющиеся языковые единицы. Подобные парцелляты, в зависимости от семасиологической нагруженности включенных конституентов (а), позволяют усилить эмоциональнооценочный компонент высказывания, при этом грамматически их можно отнести к условиям, способствующим парцелляции:

(17) Но прежде, чем перейдем к информациям и докладам, хотел бы сказать несколько слов. Мы видим с вами, что обстановка меняется практичес- 


\section{РЕЧЕВЫЕ МЕХАНИЗМЫ И ЕДИНИЦЫ ТЕКСТОВОЙ КОММУНИКАЦИИ}

ки ежедневно. И к сожалению, не в лучшую сторону (Президент России. URL: http://kremlin.ru/ events/president/news/63194);

(18) Особого внимания требуют, безусловно, беременные женщины, будущие мамы. И конечно, дети, в том числе новорожденные (Президент России. URL: http://kremlin.ru/events/president/ news/63229).

Тропофигура парцелляции, организованная на основе позиционно-лексического повтора (б), не относится к наиболее продуктивным в политическом дискурсе, однако незаменима в тех случаях, когда необходимо большое эмоциональное вовлечение «разнородной» аудитории: синтаксическая гибкость и вариативность фрагментов данной модели, обусловливающая расширение семантики парцеллированного предиката, обеспечивает гармоничный переход от одной части к другой и помогает дважды (и более) зафиксировать внимание реципиента на особо значимых элементах информации:

(19) А сегодняшнее духовное, радостное и светлое событие, многовековые традиции Пасхального праздника также помогут и поддержат каждого из нас, укрепят нашу надежду и веру. Потому что Пасха, Воскресение Христово - это символ торжества жизни над всем тем, что против нее. Это символ очищения, возрождения и продолжсения жсизни (Президент России. URL: http://kremlin.ru/events/president/news/ 63222);

(20) Каких только звонков, писем, сообщений я за эти дни не получала. Со всего мира. И коллцентр, сообщения которого мы в ручную разбираем в ДИПе, помогая коллегам, и звонки от совершенно неизвестных людей с Филипाин, у которых кроме документов и телефона нет ничего, и крики матери, что ее дочь в Праге одна... Регионы, уполномоченные, туристы, депутаты, домохязяйки, дальнобойщики....Но об одном звонке хочу рассказать отдельно. Вчера звонят люди. Лично их не знаю. Как выяснилось, обеспеченные. Даже богаmые. Очень богатые. Настолько, что <.... (Facebook. M. Захарова. URL: https://www.facebook. com/maria.zakharova.167?epa $=$ SEARCH_BOX ).

Примеры (19), (20) примечательны также расчленением элементов сложного предложения: контекстуальные связи парцеллируемого компонента усложняются, что приводит к его текстовой обособленности. Важным при анализе таких моделей становится антропоцентричность тропофигуры парцелляции, детерминированная иллокутивными намерениями автора. В одних случаях актуализируется референциальное единство партиципантов (что не исключает императивности), характеризующее аксиологическую общность власти и народа; парцеллят нейтрален и является логическим усилением указания на причину:

(21) Для всех нас - для федеральных, региональных органов власти - крайне важны ваши профессиональные оценки и рекомендации. Поэтому будем и далыше находиться с вами на постоянной связи (Президент России. URL: http://kremlin.ru/ events/president/news/63229);

(22) Хочу особо обратиться к врачам, фельдшерам, медицинским сестрам, сотрудникам больниц, поликлиник, ФАПов, служб скорой помощчи, $\kappa$ нашим ученылм. Bы сейчас на переднем крае защиты страны. Сердечно благодарю всех вас за самоотверженный труд. Также прошу губернаторов ускорить передачу необходимой информации из региональных загсов в налоговую службу. Колле$z u$, это принципиально важно, чтобы начать выплаты. Обратите на это внимание (Президент России. URL: http://kremlin.ru/events/president/news/ 63061).

В других случаях фиксируется несовпадение речевого членения с грамматическим, внимание интонационно акцентируется на зависимом положении парцеллята, в результате чего усиливается апеллятивный эффект всей конструкции:

(23) По Марокко. Читаю «посольство отделывается отговорками, что вопрос решается». Это не отговорки. Он действительно решается. В данный момент идет межведомственное совещание по логистике вывоза россиян из этой и других стран. Все понимаю. Болыше, чем вы думаете, так как круглосуточно общаемся со всеми уголками мира. И слово «потерпите» произношу с трудом, потому что знаю все обстоятельства в подробностях. Около 9 тысяч человек ждут разрешения вопроса с возвращением на Родину. Занимаемся. Все вместе. Круглосуточно (Facebook. M. Захарова. URL: https:// www.facebook.com/maria.zakharova.167?epa= SEARCH_BOX);

(24) Прибыли в Питер. Вывозные рейсы организуются в строгом соответствии с требованиями Штаба. Люди возвращаются домой. Не к кому-то домой, а к себе домой (Facebook. M. Захарова. URL: 
https://www.facebook.com/maria.zakharova.167?epa= SEARCH BOX);

(25) Давайте пообещаем себе, когда это закончится, ценить и любить жизнь, дорожить каждым моментом, радоваться окружающему миру и беречь друг друга. Хотя нет. Начинать надо уже сейчас (Facebook. M. Захарова. URL: https://www. facebook.com/maria.zakharova.167?epa=SEARCH_BOX).

Отметим и явную эллиптичность парцеллятов, демонстрирующую общеязыковую тенденцию амбивалентности использования речевых средств - соединения «экономичности» с «изобразительностью» (и компенсации вторым компонентом первого). Такая дискретность передает расщепленный «поток сознания» человека, создает фрагментарность, подвижность, динамизм. Соответственно, тропофигура парцелляции позволяет показать непосредственное движение человеческой мысли, «не обработанной» по ортологическим законам:

(26) Прошло три недели, и вот вам история очевидца. Живой человек. Можно задать вопросы. Подискутировать. Никакой «руки Кремля», только прямая речь свидетеля. Мы не знакомы. Есть пара общих друзей, но только в сети (Facebook. M. Захарова. URL: https://www.facebook.com/ maria.zakharova.167?epa=SEARCH_BOX).

Последние примеры $(23,25,26)$ демонстрируют также конвергентность орнаментальных конструкций: первый парцеллят усиливается последующим, в результате чего вычленяется градационный ряд, семантически «усиленный» разнохарактерностью референциальной отнесенности вербального знака. Детерминирующим признаком такого явления в политическом взаимодействии следует обозначить фактор осознанности автором - рефлексированности - построения и употребления тропофигуры, поскольку в данном случае мы имеем дело со строго организованным иллокутивным актом, реализующим определенные интенции.

Таким образом, тропофигуры иронии и парцелляции, имеющие сложнейшую когнитивную природу (специфические взаимоотношения между прямым / метафорическим / узуальным / окказиональным значениями, между формой и содержанием синтаксической модели; интертекстуальный характер дейксиca, градуально представленный на больших отрезках текста; несоответствия между традиционно и ситуативно обозначенным; транспозиция синтаксических структур и - шире факт структурирования воздействующего текста по принципу расчлененности со смещением рематического компонента в самостоятельную синтагму при минимизации языковых средств), наполняющие и видоизменяющие дискурсивное пространство политического взаимодействия, существенно расширяют набор конструирования новых коммуникативных единиц.

\section{Заключение}

Политический дискурс, представляя собой ярко выраженную эмоциогенную среду, оказывается «сверхчувствительной компонентой» современной российской логосферы, где новые формы коммуникативного взамодействия, транслирующиеся в иные дискурсивные интеракции, не только создаются, но и, что важнее, отрабатываются и закрепляются в качестве эталонных моделей. При этом соотношение информации (нередко негативной) и ее позитивной языковой категоризации обеспечивается определенными идиостилистическими средствами, вызывающими необходимый автору эмоциональный отклик, поскольку, как справедливо отмечает С.В. Ионова, «не существует неэмоциональных языковых личностей и все языковые, речевые, текстовые произведения, создаваемые homo sentries, всегда актуально или потенциально эмотивны» [Ионова, 2015, с. 23].

Переходный характер тропофигур иронии и парцелляции, иллокутивная косвенность и нетипичность их моделей детерминируют высочайшую степень экспрессии в свернутой «упаковке», актуализируют процесс эмотивно-интеллектуального воздействия и тем самым обеспечивают успешную реализацию прагматической цели. Будучи в своей основе стилистическими фигурами с вполне определенными синтаксическими структурами, они в то же время являются, как и классические тропы (метафора, метонимия и др.), формами эмотивно-художественного мышления, содержащими многоплановое приращение смыс- 


\section{РЕЧЕВЫЕ МЕХАНИЗМЫ И ЕДИНИЦЫ ТЕКСТОВОЙ КОММУНИКАЦИИ}

ла в акте ценностно-идеологического освоения действительности. Более того, при идиомаркированной (авторской) экспликации данных языковых знаков акцентуируются явления реляционного плана, сам характер, тип сцепления отрезков текста несет значимую семасиологическую и стилистическую нагрузку: мир, понимаемый через сопоставление / расширение неких разнородных понятий, а priori многослоен. Конвергентность категориальных признаков тропофигур многократно повышает интерпретационно-воздействующий потенциал высказывания и тем самым обеспечивает специфическую институциональность политической практики.

Таким образом, тропофигуры иронии и парцелляции, представляя собой универсальные явления полифункционального характера, обладающие неограниченной возможностью реализации интенционального вектора высказывания, оказываются как способом выражения отношения к миру (зависимым от ментальных особенностей определенного этноса), так и способом отражения этого мира, что позволяет рассматривать их в качестве лингвокультурных спецификаторов современного политического дискурса.

\section{ПРИМЕЧАНИЯ}

${ }^{1}$ Статья выполнена при поддержке РФФИ, проекты № 19-312-90069 «Ирония как способ экспликации лингвокультурных особенностей современной политической коммуникации» (Н.А. Боженкова, Т.И. Каличкина), № 18-012-00574 «Лингвокультурные доминанты легитимных /нелегитимных политических дискурсивных практик в пространстве русскоязычной коммуникации: типологическое исследование» (Н.А. Боженкова, Т.И. Каличкина, А.П. Пантелеева).

The reported study was funded by RFBR, grant number 19-312-90069 «Irony as the way of explication of the linguistic and cultural features of modern political communication» (N.A. Bozhenkova, T.I. Kalichkina), grant number 18-012-00574 «Linguocultural dominants of legitimate / illegitimate political discursive practices in the space of Russianlanguage communication: the typological research» (N.A. Bozhenkova, T.I. Kalichkina, A.P. Panteleeva).

2 Такая радикальная переоценка лучше и полнее других авторов была сделана М.А. Петровским («Фигура», 1925) и нашла свое системное подкрепление в работах Л.К. Граудиной, В.И. Королькова,
Ю.М. Скребнева, А.П. Сковородникова, Цв. Тодорова, Т.Г. Хазагерова, Л.С. Шириной и др.

${ }^{3}$ Показательны в этом отношении словарная статья о фигурах речи в энциклопедии «Русский язык», начинающаяся определением: «Фигуры речи, риторические, стилистические фигуры, - в широком смысле: любые языковые средства, включая тропы, придающие речи образность и выразительность» [Русский язык..., 1979, с. 368], и работы А. Бэна, который категорически утверждал: «...различение тропов и фигур - это различение внешнее и не имеет практического значения» [Бэн, 1886, с. 8]. Такой - синкретический - подход к проблеме, нивелирующий саму постановку вопроса о соотношении тропа и фигуры, находит свое отражение в значительном количестве риторических исследований и в наши дни.

${ }^{4}$ Впервые разделение изобразительных средств языка на тропы (фигуры речи) и собственно стилистические фигуры (фигуры мысли) встречается в «Риторике для Геренния» (86-82 гг. до н. э.), далее постулируется в работах Квинтилиана, во многих русских риториках и курсах словесности (см. описание Н.Ф. Кошанского: «Тропы - язык воображения, пленительный и живописный, основанный на подобиях и разных отношениях; а фигуры язык страстей, сильный и разительный, свойственный оратору в жару чувств, в стремлении души, в пылком движении сердца» [Кошанский, 1829, c. 118]). Приверженцами именно такой точки зрения - необходимости раздельного изучения тропов и фигур - являются многие современные лингвисты.

5 Публикации, в которых троп и фигура предстают как некое нерасчлененное целое, продолжают появляться и в наши дни. Так, «Общая риторика группы $\mu »$ [Дюбуа и др., 1986] включает в типологию всех языковых фигур и тропы, квалифицируемые на уровне метасемем.

${ }^{6}$ Наблюдается превалирование диалогической коммуникативной парадигмы по отношению к монологической, что предполагает более тесное общение с адресантом и, соответственно, усиление эффекта речевого воздействия.

${ }^{7}$ Отдельные положения данного раздела исследования были апробированы в формате магистерской диссертации [Каличкина, 2017].

${ }^{8}$ См. также словарь Д.М. Ушакова - «риторическая фигура, в которой слова употребляются в смысле, обратном буквальному, с целью насмешки» (Ушаков); словарь С.И. Ожегова, Н.Ю. Шведовой - «тонкая, скрытая насмешка» (Ожегов, Шведова).

${ }^{9}$ В современных исследованиях встречается и такая дефиниция: «Специальный прием коммуникативно-стилистической организации текста, предназначенный для усиленного эмоционально- 
го и интеллектуального воздействия на адресата информации» [Богоявленская, 2013, с. 128].

\section{СПИСОК ЛИТЕРАТУРЫ}

Богоявленская Ю. В., 2013. Парцелляция в сильных позициях медиатекста // Политическая лингвистика. № 1. С. 128-132.

Боженкова Н. А., Боженкова Р. К., 2019. Зевгматические и парцеллированные конструкции как семасиологические идентификаторы политического дискурсивного взаимодействия // II Всемирный конгресс в реальном и виртуальном пространстве «Восток-Запад: пересечения культур». Киото : Tanaka Print. C. 254-261.

Боженкова Н. А., Боженкова Р. К., 2020. Парцелляция как лингвокогнитивный идентификатор российского политического дискурса // Горизонты современной русистики : сб. ст. Междунар. науч. конф., посвящ. 90-летнему юбилею акад. В.Г. Костомарова. М. : Гос. ин-т рус. яз. им. А.С. Пушкина. С. 125-131.

Боженкова Н. А., Боженкова Р. К., Боженкова А. М., 2017. Современный политический дискурс: вербальная экземплификация тактико-стратегических предпочтений коммуникантов в современных политических дискурсивных практиках // Вестник РУДН. Серия «Русский и иностранный языки и методика их преподавания». Т. 15, № 3. С. 255-284. DOI: https://doi.org/ 10.22363/2313-2264-2017-15-3-255-284.

Боженкова Н. А., Катышев П. А., Ионова С. В., Афанасьева Э. М., Саакян Л. Н., 2019. Русский политический дискурс в фокусе лингвоэкологии // Вестник Волгоградского государственного университета. Серия 2, Языкознание. Т. 18, № 3. С. 76-92. DOI: https://doi.org/ 10.15688/jvolsu2.2019.3.6.

Бэн А., 1886. Стилистика и теория устной и письменной речи. М. : Тип. В. В. Исленьева. XXVI, 293 с.

Ванников Ю. В., 1979. Синтаксис речи и синтаксические особенности русской речи. М. : Рус. яз. $296 \mathrm{c}$.

Водак Р., 2011. Критическая лингвистика и критический анализ дискурса // Политическая лингвистика. № 4 (38). С. 24-34.

Горнфельд А., 1911. Фигура в поэтике и риторике // Вопросы теории и психологии творчества. В 2 т. Т. 1. Фигура в поэтике и риторике. Изд. 2-е. Харьков : Мирный труд. С. 335-339.

Дюбуа Ж., Эделин Ф., Клинкенберг Ж.-М. [и др.], 1986. Общая риторика группы $\mu$ / пер. с фр. Е. Э. Разлоговой, Б. П. Нарумова ; общ. ред. и вступ. ст. А. К. Авеличева. М. : Прогресс. 392 с.
Зольгер К. В. Ф., 1978. Эрвин. Четыре диалога о прекрасном и об искусстве. М. : Искусство. 432 с.

Ионова С. В., 2015. Эмоциональные эффекты позитивной формы общения // Вестник Российского университета дружбы народов. Серия: Лингвистика. № 1. С. 20-30.

Каличкина Т. И., 2017. Ирония как репрезентант лингвокультурных особенностей русскоязычного и тюркоязычного институционального дискурса : магистр. дис. M. 113 c. URL: https:// biblioclub.ru/index.php?page $=$ book\&id $=462031$ (дата обращения: 20.07.2020).

Корольков В. И., 1974. К теории фигур // Сборник трудов Московского госпединститута им. М. Тореза. Вып. 78. С. 60-93.

Кошанский Н. Ф., 1829. Общая риторика. СПб. : Тип. Мед. департамента М-ва внутр. дел. 152 с.

Новиков Л. А., 2002. Поэтическое противоречие // Вестник РУДН. Серия: Лингвистика. № 3. C. $122-129$.

Панков Ф. И., 2019. Сегмент и парцеллят как синтаксические позиции словоформ // Русское слово в многоязычном мире : материалы XIV Конгр. МАПРЯЛ (г. Нур-Султан, Казахстан, 29 апр. - 3 мая 2019 г.) / редкол.: Н. А. Боженкова, С. В. Вяткина, Н. И. Клушина [и др.]. СПб. : МАПРЯЛ. С. 765-770.

Потебня А. А., 1990. Теоретическая поэтика. М. : Высш. шк. 344 с.

Русский язык: энциклопедия, 1979 / гл. ред. Ф. П. Филин. М. : Сов. энцикл. 432 с.

Сковородников А. П., 1981. Экспрессивные синтаксические конструкции современного русского литературного языка. Опыт системного исследования. Томск : Изд-во Том. ун-та. 255 с.

Стернин И. А., 2003. Социальные факторы и публицистический дискурс // Массовая культура на рубеже XX-XXI вв. : Человек и его дискурс. М. : Азбуковник. С. 91-108.

Шаховский В. И., 2008. Лингвистическая теория эмоций. М. : Гнозис. 416 с.

\section{СЛОВАРИ}

$Б A C$ - Словарь современного русского литературного языка. В 17 т. Т. 16. М. ; Л. : АН СССР, 1965. 1610 стб.

Даль - Даль В. И. Толковый словарь живого великорусского языка. В 4 т. М. : Дрофа, 2011. 4 т.

Ожегов, Шведова - Ожегов С. И., Шведова Н. Ю. Толковый словарь русского языка. URL: http:// ozhegov.info/slovar $/ \mathrm{q}=\% \mathrm{D} 0 \% \mathrm{~B} 8 \% \mathrm{D} 1 \% 80 \%$ $\mathrm{D} 0 \% \mathrm{BE} \% \mathrm{D} 0 \% \mathrm{BD} \% \mathrm{D} 0 \% \mathrm{~B} 8 \% \mathrm{D} 1 \% 8 \mathrm{~F}$ (дата обращения: 20.07.2020). 
Ушаков - Ушаков Д. Н. Толковый словарь русского языка. URL: https://ushakovdictionary.ru/ word.php?wordid=21495 (дата обращения: 20.07.2020).

\section{REFERENCES}

Bogoyavlenskaya Yu.V., 2013. Partsellyatsiya v silnykh pozitsiyakh mediateksta [Parcellation in strong positions ofmedia text]. Politicheskaya lingvistika [Political linguistics], no. 1, pp. 128-132.

Bozhenkova N.A., Bozhenkova R.K., 2019. Zevgmaticheskie i partsellirovannye konstruktsii kak semasiologicheskie identifikatory politicheskogo diskursivnogo vzaimodeystviya [Zeugmatic and parceled constructions as semasiological identifiers of political discursive interaction]. II Vsemirnyy kongress $v$ realnom $i$ virtual'nom prostranstve "Vostok-Zapad: peresecheniya kultur" [Proceedings II World Congress in Real and Virtual Mode "East-West: the intersection of culture"]. Kioto, Universitet Kioto Sange, Tanaka Print, pp. 254-261.

Bozhenkova N.A., Bozhenkova R.K., 2020. Partsellyatsiya kak lingvokognitivnyy identifikator Rossiyskogo politicheskogo diskursa [Parceled constructions as a linguocognitive identifier of Russian political discourse]. Gorizonty sovremennoy rusistiki : sb. st. Mezhdun. nauch. konf., posvyashchennoy 90-letnemu yubileyu akademika V.G. Kostomarova [Proc. Int. sci. conf., dedicated to the 90th anniversary of Academician V.G. Kostomarov "Horizons of modern Russian studies"]. Moscow, Pushkin State Russian Language Institute, pp. 125-131.

Bozhenkova N.A., Bozhenkova R.K., Bozhenkova A.M., 2017. Sovremenniy politicheskiy diskurs: verbalnaya ekzemplifikatsiya taktikostrategicheskikh predpochteniy kommunikantov v sovremennykh politicheskikh diskursivnykh praktikakh [Modern political discourse: verbal exemplification of tactical and strategic preferences]. Vestnik RUDN. Seriya "Russkiy i inostrannyy yazyki $i$ metodika ikh prepodavaniya” [RUDN journal of Russian and foreign languages research and teaching], vol. 15 , no. 3 , pp. 255284. DOI: 10.22363/2313-2264-2017-15-3-255-284.

Bozhenkova N.A., Katyshev P.A., Ionova S.V., Afanaseva E.M., Saakyan L.N., 2019. Russkiy politicheskiy diskurs $\mathrm{v}$ fokuse lingvoekologii [Russian political discourse in the focus of linguistic ecology]. Vestnik Volgogradskogo gosudarstvennogo universiteta. Seriya 2. Yazykoznanie [Science Journal of Volgograd
State University. Linguistics], vol. 18, no. 3, pp. 76-92. DOI: https://doi.org/10.15688/jvolsu2. 2019.3.6.

Bain A., 1886. Stilistika i teoriya ustnoy i pismennoy rech $i$ [Stylistics and theory of oral and written speech]. Moscow, V. V. Islenev's printing house. XXVI, 293 p.

Vannikov Yu.V., 1979. Sintaksis rechi i sintaksicheskie osobennosti russkoy rechi [Speech syntax and syntactic features of Russian speech]. Moscow, Russkiy yazyk Publ. 296 p.

Wodak R., 2011. Kriticheskaya lingvistika i kriticheskiy analiz diskursa [Critical linguistics and critical discourse analysis]. Politicheskaya lingvistika [Political linguistics], no. 4 (38), pp. 24-34.

Gornfeld A., 1911. Figura v poetike i ritorike [A figure in poetics and rhetoric]. Voprosy teorii $i$ psikhologii tvorchestva: posobiye pri izuchenii teorii slovesnosti $v$ vysshikh i srednikh uchebnykh zavedeniyakh. V 2 t. T. 1 [Questions of theory and psychology of creativity: A guide for the study of literature in higher and secondary educational institutions. In 2 vols. Vol. 1]. Kharkov, Mirnyy trud Publ., pp. 335-339.

Dubois J., Edelin F., Klinkenberg J.-M. et al., 1986. Obshchaya ritorika gruppy $\mu$ [General rhetoric of the $\mu$ group] Moscow, Progress Publ. 392 p.

Solger K.W.F., 1978. Ervin. Chetyre dialoga o prekrasnom $i$ ob iskusstve [Erwin. Four dialogues on beauty and art]. Moscow, Iskusstvo Publ. $432 \mathrm{p}$.

Ionova S.V., 2015. Emotsionalnye effekty pozitivnoy formy obshcheniya [Emotional effects of positive forms of communication]. Vestnik RUDN. Seriya: Lingvistika [Russian journal of linguistics], no. 1, pp. 20-30.

Kalichkina T.I., 2017. Ironiya kak reprezentant lingvokulturnykh osobennostey russkoyazychnogo i turkoyazychnogo institutsionalnogo diskursa: magist. dis. [Irony as a representative of the linguocultural characteristics of the Russianspeaking and Turkic-speaking institutional discourse. Master's thesis]. Moscow. 113 p. URL: ht tps://biblioclub.ru/index.php? page $=$ book\&id $=462031$ (accessed 20 July 2020).

Korolkov V.I., 1974. K teorii figure [On the figure theory]. Sbornik trudov Moskovskogo gospedinstituta im. M. Toreza [Proceedings of the Moscow Pedagogical State University], iss. 78, pp. 60-93.

Koshanskiy N.F., 1829. Obshchaya ritorika [General rhetoric]. Saint Petersburg, Tipografiya Meditsinskogo departamenta vnutrennikh del. $152 \mathrm{p}$.

Novikov L.A., 2002. Poeticheskoe protivorechie [Figura contradictionis]. Vestnik RUDN. Seriya: 
Lingvistika [Russian journal of linguistics], no. 3, pp. 122-129.

Pankov F.I., 2019. Segment i partsellyat kak sintaksicheskie pozitsii slovoform [Segment and parcel as syntactic positions of word forms: a fragment of a linguodidactic model of Russian grammar]. Russkoe slovo $v$ mnogoyazychnom mire: materialy XIV Kongr. MAPRYaL [Proceedings XIV Congress MAPRYAL "The Russian word in the multilingual world"]. Saint Petersburg, MAPRYAL, pp. 765-770.

Potebnya A.A., 1990. Teoreticheskaya poetika [Theoretical poetics]. Moscow, Vysshaya shkola Publ. 344 p.

Filin F.P., ed., 1979. Russkiy yazyk: entsiklopediya [Russian language: encyclopedia]. Moscow, Sovetskaya entsiklopediya Publ. 432 p.

Skovorodnikov A.P., 1981. Ekspressivnye sintaksicheskie konstruktsii sovremennogo russkogo literaturnogo yazyka. Opyt sistemnogo issledovaniya [Expressive syntactic constructions of the modern Russian literary language. Systems research experience]. Tomsk, Izd-vo Tomskogo universiteta. $255 \mathrm{p}$.

Sternin I.A., 2003. Sotsialnye faktory i publitsisticheskiy diskurs [Social factors and publicistic discourse]. Massovaya kultura na rubezhe $X X-X X I$ vv.:
Chelovek $i$ ego diskurs [Popular culture at the turn of the 20-2 $1^{\text {th }}$ centuries. Man and his discourse]. Moscow, Azbukovnik Publ.,pp. 91-108.

Shakhovskiy V.I.. 2008. Lingvisticheskaya teoriya emotsiy [Linguistic theory of emotions]. Moscow, Gnozis Publ. 416 p.

\section{DICTIONARIES}

Slovar sovremennogo russkogo literaturnogo yazyka. $V 17$ t. T. 16 [Dictionary of modern Russian literary language. In 17 vols. Vol. 16]. Moscow, Leningrad, AN SSSR, 1965. 1610 cols.

Dal V.I. Tolkovyy slovar zhivogo velikorusskogo yazyka. $V 4 \mathrm{t}$. [Explanatory dictionary of the living great Russian language. In 4 vols.]. Moscow, Drofa Publ., 2011.

Ozhegov S.I., Shvedova N.Yu. Tolkovyy slovar russkogo yazyka [Explanatory dictionary of the Russian language]. 1992. URL: http:// ozhegov.info/slovar?q=ирония (accessed 20 July 2020).

Ushakov D.N. Tolkovyy slovar russkogo yazyka [Explanatory dictionary of the Russian language]. URL: https://ushakovdictionary.ru/word.php? wordid=21495 (accessed 20 July 2020).

\section{Information About the Authors}

Natalya A. Bozhenkova, Doctor of Sciences (Philology), Professor, Department of General and Russian Linguistics, Pushkin State Russian Language Institute, Akademika Volgina St, 6, 117485 Moscow, Russia, natalyach@mail.ru, https://orcid.org/0000-0002-2381-5865

Tamara I. Kalichkina, Postgraduate Student, Pushkin State Russian Language Institute, Akademika Volgina St, 6, 117485 Moscow, Russia, toma.kalichkina@gmail.com, https://orcid.org/0000-0002-0728-5323

Aleksandra P. Panteleeva, Postgraduate Student, Pushkin State Russian Language Institute, Akademika Volgina St, 6, 117485 Moscow, Russia, panteleeva-alex@mail.ru, https://orcid.org/0000-0002-2295-3780

\section{Информация об авторах}

Наталья Александровна Боженкова, доктор филологических наук, профессор кафедры общего и русского языкознания, Государственный институт русского языка им. А.С. Пушкина, ул. Академика Волгина, 6, 117485 г. Москва, Россия, natalyach@mail.ru, https://orcid.org/0000-0002-2381-5865

Тамара Игоревна Каличкина, аспирант, Государственный институт русского языка им. А.С. Пушкина, ул. Академика Волгина, 6, 117485 г. Москва, Россия, toma.kalichkina@gmail.com, https://orcid.org/0000-0002-0728-5323

Александра Павловна Пантелеева, аспирант, Государственный институт русского языка им. А.С. Пушкина, ул. Академика Волгина, 6, 117485 г. Москва, Россия, panteleeva-alex@mail.ru, https://orcid.org/0000-0002-2295-3780 